\title{
Gérard Duménil and Dominique Lévy, The Crisis of Neoliberalism (Cambridge: Harvard University Press, 2010).
}

This comprehensive volume represents quite an impressive contribution to the growing literature on neoliberal globalisation and financialisation. Indeed, the broad historical sweep of the narrative elevates this book to the very apex of Marxian scholarship, if not of recent scholarship in general. At the risk of oversimplification, the basic kernel of the argument developed by the authors is that the crisis of neoliberalism represents a profound structural crisis, analogous to the period of the late nineteenth century preceding the First World War. In the tradition of the "world systems" literature (i.e., Arrighi, Wallerstein, etc), the current structural crisis has been characterised by a "hegemonic transition" from US global hegemony towards a possible new tri-polar world order. As the authors note:

The crisis of Neoliberalism is the fourth structural crisis in capitalism since the late nineteenth century. Each of these earthquakes introduced the establishment of a new social order and deeply altered international relations. The contemporary crisis marks the beginning of a similar process of transition. ... Accordingly, countries such as China, India or Brazil will become gradually less dependent on this relationship to the US. It will be, in particular, quite difficult to correct for the macro trajectory of declining trends of accumulation and cumulative disequilibria of the US economy once the Great

Contraction is stopped (2).

The outcome of the crisis of US hegemony will ultimately depend upon the evolution of the configuration of class forces both within the US and on a global scale. In other words, the crisis of neoliberalism will bring about a new class compromise between the three major class fractions, which the authors designate as: (1) the capitalist classes, (2) the managerial classes and (3), the popular classes. A Left compromise is viewed as a new alliance between the popular classes and the managerial classes, similar to the New Deal in the US during the 1930s and the post-war social democratic/Keynesian consensus. On the other hand, a social compromise on the Right - which the authors believe will be the most likely outcome of the current crisis - involves a grand compromise between the managerial classes and the capitalist classes (19). This configuration of class forces appears to be rather limited. A more sophisticated class analysis should include the strategic and potentially destabilising role performed by a declining petty bourgeoisie and the growing ranks of the unemployed.

The authors' analyses of the current crisis are quite unique in the sense that, 
unlike other heterodox explanations of the underlying causes, they dispute any real technical causes: "There is no symptomatic technical explanation of the crisis. It was not the effect of deficient profit rates. It was also not the consequence of a lack of demand, the expression of the insufficient purchasing power of wages" (33-34). Their alternative explanation is summarised in Diagram 2.1 (34):

\section{Diagram 2.1}

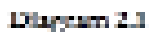

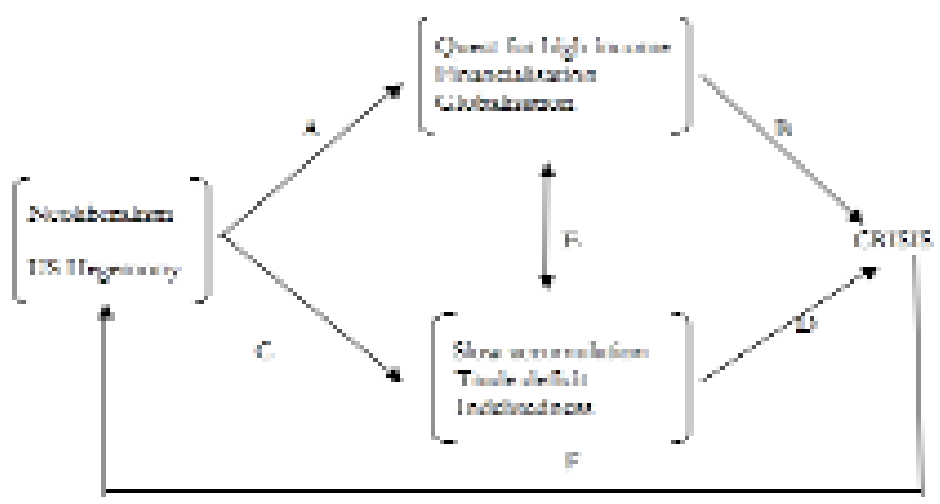

Their thesis rejects conventional over-accumulation/under-consumption explanations of the crisis. Instead, the problem ostensibly lies in the extreme income inequalities generated by neoliberal restructuring over the past three decades. These social trends led to the emergence of "over-consumption" by the managerial classes, which existed alongside relative under-consumption by the popular classes. Although the authors acknowledge the problems of rising household debt, which was a major catalyst in the growth of financialisation, they also argue that one of the unique features of the neoliberal era was the extraordinary rise in the indebtedness of the financial sector itself: "Much attention is devoted to the soaring debt of households, and not erroneously, but the growing indebtedness of the financial sector is also a major feature of the neoliberal decades. ... Thus, the indebtedness of the financial sector is a new and spectacular phenomenon, typical of the neoliberal decades" (104).

It was, therefore, the pursuit of higher profits and income by the capitalist classes and their subaltern managerial classes that was responsible for the spectacular growth of fictitious capital (125). The other major structural causes of the crisis are the manifestations of the overall macro trajectory of the US economy. Central to this structural decline has been the worsening external balance 
and low and declining accumulation rates. The authors view this structural decline as potentially quite ominous, which could prefigure the emergence of a serious dollar crisis and the eventual demise of US global hegemony. The diagnosis of the structural causes of the crisis lends itself to several possible future scenarios in a post-neoliberal social order:

A likely list of the developments that would stimulate new dynamics is as follows: (1) the weakness of the economic recovery and the likelihood of a new contraction of GDP, (2) the threat of the repetition of a new episode of financial perturbations, (3) a crisis of the dollar, and (4) the multiplication of new symptoms of the lost economic pre-eminence of the US (237).

The only real criticism proposed is that the authors have inexplicably ignored Minsky's financial instability hypothesis, which has led many heterodox economists (and some orthodox economists as well) to describe the financial meltdown as a "Minsky moment". Similarly, Fisher's debt-deflation theory of depressions is only mentioned briefly. The arguments developed in this volume could have been considerably reinforced by incorporating a Minsky-Fisher theoretical framework. Despite these reservations, this volume is an original and critical contribution to recent heterodox debates over the critical dynamics of neoliberal globalisation and the growing literature devoted to the phenomenon of financialisation. Indeed, the impressive arsenal of statistical evidence deployed to support the central arguments by the authors makes this volume essential reading.

Bill Lucarelli

University of Western Sydney

\section{Janice R. Foley and Patricia Baker, Eds. Unions, Equity, and the Path to Renewal (Vancouver: UBC Press, 2010).}

Unions, Equity, and the Path to Renewal, edited by Janice R. Foley and Patricia Baker, makes a useful contribution in support of the struggle to revitalize the union movement, not least by disputing the argument that equity is a frill that unions, currently under attack and preoccupied with the fight for their very existence, can ill-afford. On the contrary, the contributors - who are remarkably consistent on this point - argue that progress toward equity is essential to union renewal and revitalization. Indeed, they insist that unions have lost much of their former relevance largely because they have failed to support their female and racialized members.

The book, like many others in the genre, is a collaboration between union activists and activist scholars, an approach that links the experience of 